\title{
The Barriers and Solutions to Integration of the EAFTA and TPP
}

\author{
Goro Takahashi
}

Published online: 29 August 2013

(C) CEEUN 2013

\begin{abstract}
The EAFTA (East Asia Free Trade Area) and TPP (Trans Pacific Partnership) will likely be unified in the future to form the FTAAP (Free Trade Area of the Asia Pacific). I have analyzed these two types of FTAs and studied the barriers and solutions to their integration. Furthermore, the process by which the FTAAP will convert into the Asia Pacific Community (APC), equipped with larger terms and conditions, is also considered. The largest barrier to the integration of EAFTA and the TPP is the agreement over sensitive problems, such as import tariffs. The difference in posture about such sensitive problems in these two economic organizations is analyzed beneath, and it is claimed that a viable solution exists. As far as sensitive problems are concerned, it is clear that EAFTA takes a cooperative stance and that TPP is more severe. In the case that these two economic organizations are eventually unified, such differences will become major obstacles to integration. However, these differences will also serve as the terms of promotion and conditions to integration. Just as there are differences, we can also recognize the necessity for mutual complements. The case of the EU can be applied to this. The unification of 28 states to form the EU was not achieved because of the comparability argument; it was achieved thanks to the differences which exist between member states. Although the EU is in a state of historical crisis, the cause of this lies in the failure of the public-finance policy of certain member states. While learning from the EU experience, EAFTA and the TPP should merge to form the FTAAP, with the ultimate goal of APC establishment in the future.
\end{abstract}

Keywords EAFTA $($ ASEAN + 3) $\cdot$ TPP $\cdot$ CJKFTA $\cdot$ Integration · FTAAP · APC

G. Takahashi $(\bowtie)$

International Center for Chinese Studies, Aichi University, Aichi 453-8777, Japan

e-mail: takaha@vega.aichi-u.ac.jp 


\section{Introduction}

Based on the APEC Yokohama vision (2010), as Fig. 1 demonstrates, EAFTA $($ ASEAN +3 (3 = China, Japan, Korea: CJK)) or RCEP (EAFTA + 3 (3 = India, New Zealand, Australia) and the TPP are to be united together as the FTAAP (Free Trade Area of the Asia Pacific). Routes until it unites with FTAAP are EAFTA (or RCEP) and TPP. However, these two routes have yet to be united. This paper develops an argument, assuming the EAFTA and the TPP to be the same thing.

The purpose of this research is to clarify the barriers to integration and consider a solution, so that the FTAAP will one day be able to evolve into the Asia Pacific Community (APC).

It is clear that fundamental differences exist between the two policies of international trade deregulation vis-à-vis "sensitive sectors". In the case of the CJKFTA (China, Japan and Korea FTA) plan, conducting negotiations in a constructive and positive manner, paying due consideration to the sensitive sectors of each country is the most basic understanding in the three countries. This is also true in the case of the EAFTA plan, too. For instance, a CJKFTA study report states that "in pursuing a possible CJKFTA, due consideration should be given to the sensitive products of each country. If the issues related with sensitive products are appropriately addressed, the three countries will enjoy improved welfare generated by a CJKFTA".

We should notice that the CJKFTA at least is mild or soft in regard to consideration of sensitive products and services. If China, Japan and Korea agree to

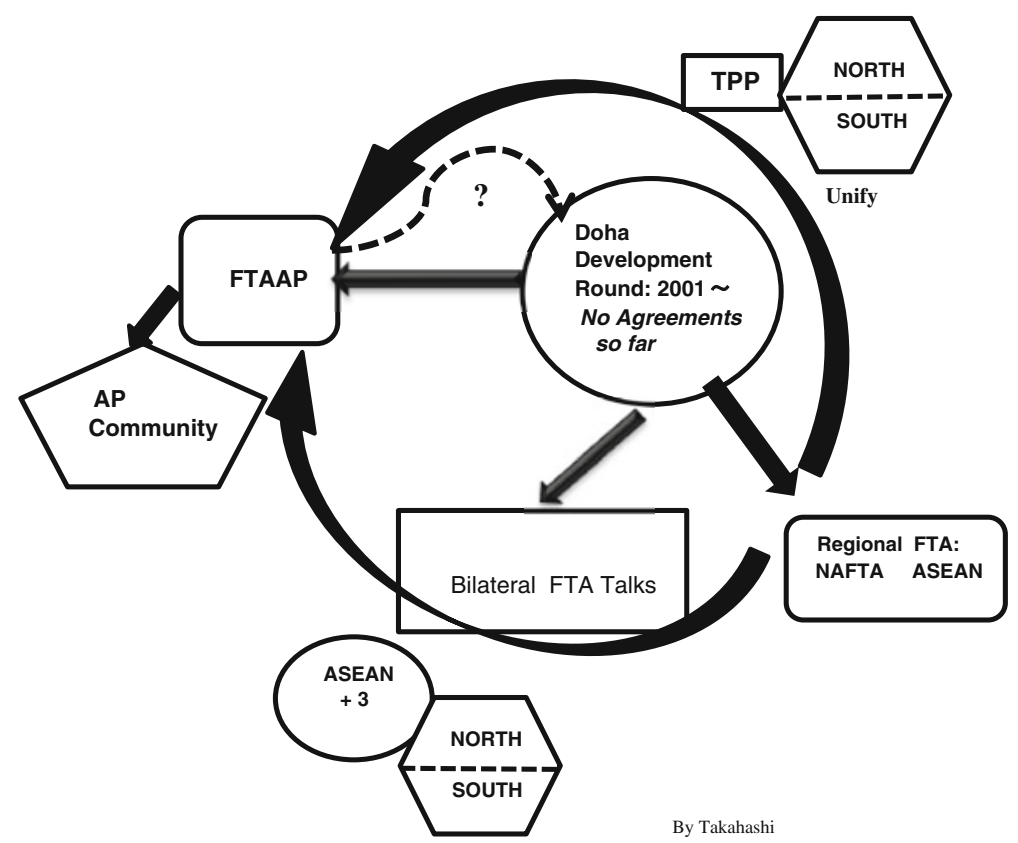

Fig. 1 Structural relation of FTA, TPP, FTAAP, ASEAN +3 and WTO 
establish the CJKFTA, they will achieve their goal of a Win-Win-Win situation. The aforementioned report states that "the three countries should not only reduce tariffs and non-tariff measures which have adverse effects on trade but also deepen and strengthen economic linkages among the three countries to establish a WinWin-Win relationship through forming a CJKFTA, with due consideration to the sensitivities of each country in these sectors".

Substantial negotiations have yet to start for the CJKFTA. China, Japan and Korea only decided on May 14, 2012 to commence negotiations within 2012. Nobody believed that negotiations would start in earnest 2012. Only China and Korea began negotiations in May 2012. Korea has so many sensitive commodities of trade to Japan; Japan, too, has many sensitive goods of trade to China and Korea.

Meanwhile, the ASEAN + 1 FTA ("+1" means China or Japan or Korea) was already achieved in the 2000s. China, Japan and Korea made treaties with ASEAN respectively. The most aggressive nation is that of Korea, as it has already established FTAs with a range of countries. The KAFTA (Korea and ASEAN FTA) took effect for the trade of commodities in June 2007, and FTAs for the trade of services with India took effect in May 2009, with the EU in July 2011, and then with US on March 15 2012. Korea will also soon begin FTA negotiations with Vietnam.

China also has been immensely successful in negotiating FTAs agreements with other countries. Examples include Singapore (2009); ASEAN (2010); the Gulf Cooperation Council (2004 ); South Africa; Chile (2004); Australia (2005); Iceland and Norway (2007); New Zealand (2008); and Pakistan (2009).

Japan has hitherto established FTAs (EPAs) with 13 countries (Switzerland, ASEAN, Vietnam, Philippines, Brunei, Indonesia, Thailand, Malaysia, Singapore, India, Chile, Mexico and Peru) and is currently in the process of negotiating deals with the GCC, Korea and Australia. Out of the CJK countries, Japan has managed to establish the greatest number of FTAs (EPAs). However, Japan's trade ratio is the lowest of the three at $18.7 \%$, compared with $35.2 \%$ for Korea and $19.4 \%$ for China. ${ }^{1}$

China, Japan and Korea are not particularly positive about the prospect of trilateral economic unification with one another; however they all demonstrate positive attitudes when it comes to integration with other countries. This situation in itself is a barrier to the construction of EAFTA. Although differences in basic economic structures of the three countries are the major factor behind delayed economic integration, I would argue that it is these differences which justify the necessity for economic unification.

On the other hand, in the case of the TPP, the nine countries have more rigid rules on sensitive sectors. The TPP does not allow its members to have "sensitive sectors". For example, the nine TPP countries continued to work on developing ambitious tariff packages that would provide access to each other's industrial, agricultural, and textiles markets. They also discussed the liberalization of their respective services and government procurement markets.

Although there are big differences in economic structure, the fact that nine countries have joined the TPP demonstrates this point. Needless to say, although the

\footnotetext{
1 Ministry of foreign affairs of Japan (2012).
} 
negotiations which take place within the TPP are severe, participating countries are taking positive measures. Although levels of cooperativeness within the TPP are bad in comparison with that of EAFTA, these two economic organizations may well be unified as one in the future.

We can assume that the CJKFTA and TPP will be unified in the future as the FTAAP. I have analyzed both FTA plans and have studied the barriers and solutions to their integration. At present, many barriers exist. The greatest barrier lies in the large difference in their participating conditions. The participating conditions for EAFTA are cooperative, while the TPP's are very severe. It would appear that this severity has continued on from the TPP's nascent years as the P4, and has increased further after the US began participating as a negotiator country.

This paper seeks to point out the barriers which bar integration of the TPP and EAFTA, and to consider a suitable policy for their unification.

\section{The Economic Situation of EAFTA and TPP Member Countries}

\section{GDP Indicator}

As demonstrated in Table 1, there are marked differences in both the GDP and GDP per capita between EAFTA and the TPP. Since this difference is unchangeable, when the two plans are unified, the premise of this difference must be carried out. China, Japan and the US occupy the top scale of GDP, whereas Laos, Cambodia, Brunei and Myanmar are very small in terms of their GDP. There is also a conspicuous difference in GDP per capita, from more than 40 thousand to 400 \$US. Nobody can remove this difference. Indeed, such a situation will likely continue for the time being. When each FTA body unites, and when set to one it is necessary to make it not become barriers.

The answer lies in understanding the merit of each FTA fusion mutually, and in how to push forward with mild integration. Advanced countries are cooperating in order to strengthen the competitive section of lesser powers. That is, it is important to respect the competitive power of the segment of the economy of each country, and an FTA is an advancing international specialization based on this principle. However, the important thing for FTAs is mutually demonstrating the soul of concession. As such, it is very important to know how EAFTA and TPP are dealing with sensitive problems.

Trade Indicators

As shown in Tables 2 and 3, the trade volume of each country is also considerably different. The US, China, Japan and Korea occupy the top 4, and accounted for $72.7 \%$ of Asian track exports in 2010. Furthermore, the US and Japan accounted for $55 \%$ of TPP track exports in the same year.

Meanwhile, exports from Laos and Cambodia occupy a very small size of total ASEAN track exports, and Brunei is the smallest TPP track exporter. However, the quantity of overseas trade is not important; the size of the contribution of trade to 
Table 1 GDP by two plans

\begin{tabular}{|c|c|c|c|c|c|c|c|}
\hline & & 1990 & $\begin{array}{l}\text { GDP } \\
2000\end{array}$ & $\begin{array}{l}(\$ 1 \mathrm{MM}) \\
2010\end{array}$ & 1990 & $\begin{array}{l}\text { Per Capita GDP } \\
2000\end{array}$ & $\begin{array}{l}\text { (US\$) } \\
2010\end{array}$ \\
\hline \multirow[t]{14}{*}{ ASEAN +3} & $\mathrm{BN}$ & 6,894 & 8,602 & 9,993 & 27,342 & 26,303 & 25,051 \\
\hline & MY & 55,084 & 109,442 & 171,826 & 3,025 & 4,674 & 6,050 \\
\hline & VN & 17,751 & 36,846 & 74,268 & 265 & 468 & 845 \\
\hline & $\mathrm{KH}$ & 2,086 & 4,027 & 8,694 & 219 & 324 & 615 \\
\hline & $\mathrm{CN}$ & 531,890 & $1,433,854$ & $3,883,522$ & 473 & 1,150 & 2,946 \\
\hline & ID & - & - & 377,282 & - & - & 1,573 \\
\hline & $\mathrm{JP}$ & $3,794,070$ & $4,265,774$ & $4,578,543$ & 31,035 & 33,931 & 36,184 \\
\hline & KR & 360,297 & 678,270 & $1,017,571$ & 8,383 & 14,749 & 21,119 \\
\hline & LA & 1,096 & 2,016 & 4,380 & 261 & 379 & 706 \\
\hline & SG & 49,663 & 99,282 & 170,969 & 16,463 & 25,332 & 33,613 \\
\hline & MM & 3,294 & 6,514 & 20,310 & 84 & 145 & 423 \\
\hline & $\mathrm{PH}$ & 62,103 & 82,358 & 131,138 & 1,008 & 1,065 & 1,406 \\
\hline & $\mathrm{TH}$ & 88,907 & 137,515 & 210,077 & 1,558 & 2,177 & 3,039 \\
\hline & Total & $4,973,134$ & $6,864,503$ & $10,658,573$ & - & - & - \\
\hline \multirow[t]{13}{*}{ TPP } & $\mathrm{BN}$ & Listed & Above & & & & \\
\hline & MY & & & & & & \\
\hline & $\mathrm{VN}$ & & & & & & \\
\hline & SG & & & & & & \\
\hline & JP & & & & & & \\
\hline & US & $8,015,276$ & $11,240,367$ & $13,094,544$ & 31,191 & 39,244 & 41,670 \\
\hline & $\mathrm{AU}$ & 451,430 & 644,740 & 874,477 & 26,405 & 337,643 & 39,270 \\
\hline & $\mathrm{NZ}$ & 69,760 & 94,774 & 121,298 & 20,530 & 24,306 & 27,769 \\
\hline & $\mathrm{PE}$ & 43,529 & 63,657 & 112,100 & 2,007 & 2,500 & 3,855 \\
\hline & $\mathrm{CL}$ & 51,765 & 96,236 & 138,703 & 3,925 & 6,241 & 8,105 \\
\hline & $\mathrm{CA}$ & 749,885 & 999,927 & $1,203,888$ & 27,071 & 32,606 & 35,391 \\
\hline & $\mathrm{MX}$ & 547,801 & 770,735 & 922,307 & 6,498 & 7,710 & 8,131 \\
\hline & Total & $13,852,908$ & $18,430,382$ & $21,472,918$ & - & - & - \\
\hline
\end{tabular}

Source UNCTADATAT.US Dollars at constant prices (2005) and constant exchange rates (2005) in millions

$A U$ Australia, $B N$ Brunei Darussalam, $C L$ Chile, $C N$ China, ID Indonesia, $J P$ Japan, $K H$ Cambodia, $K R$ Korea, $L A$ Lao People's Democratic Republic, $M M$ Myanmar, $M Y$ Malaysia, $N Z$ New Zealand, $P E$ Peru, $P H$ Philippines, $S G$ Singapore, $T H$ Thailand, $U S$ United States, $V N$ Viet Nam, $C A$ Canada, $M X$ Mexico. Also following the same

GDP is a more important index. In these terms, Korea, China, Singapore, Brunei, etc. have a very high share of trade volume in GDP, and there is a marked difference also in this index among each country. This difference cannot be done away with by anyone. At this point, the most important thing is raising national public welfare through the liberalization of foreign trade or investment.

One point which should be noted is that the total export value of EAFTA and TPP was between that of 3,700-3,800 billion dollars respectively in 2010. This 
Table 2 Export to world by EAFTA (\$1MM)

Source UNCTADSTAT. Total all products

Table 3 Export to world by TPP (\$1MM)

Source UNCTADSTAT. Total all products

\begin{tabular}{lrrr}
\hline & \multicolumn{1}{c}{1995} & \multicolumn{1}{l}{2000} & \multicolumn{1}{c}{2010} \\
\hline BN & 2,379 & 3,877 & 9,195 \\
KH & 855 & 1,389 & 5,590 \\
CN & 148,779 & 249,203 & $1,577,764$ \\
ID & - & - & 157,779 \\
JP & 442,937 & 479,276 & 769,839 \\
KR & 125,056 & 172,267 & 468,856 \\
LA & 311 & 330 & 1,746 \\
MY & 73,778 & 98,230 & 198,791 \\
MM & 860 & 1,647 & 9,455 \\
PH & 17,447 & 38,078 & 51,498 \\
SG & 118,263 & 137,806 & 351,867 \\
TH & 56,439 & 68,819 & 195,312 \\
VN & 5,449 & 14,483 & 71,658 \\
Total & 992,555 & $1,265,405$ & $3,869,349$ \\
\hline
\end{tabular}

\begin{tabular}{lrrr}
\hline & \multicolumn{1}{c}{1995} & \multicolumn{1}{c}{2000} & \multicolumn{1}{c}{2010} \\
\hline AU & 53,001 & 63,766 & 206,705 \\
CA & 191,118 & 277,113 & 385,816 \\
CL & 15,901 & 18,215 & 71,345 \\
MX & 79,541 & 166,294 & 298,305 \\
PE & 13,745 & 13,297 & 30,932 \\
NZ & 5,440 & 6,866 & 35,073 \\
US & 582,965 & 780,332 & $1,277,109$ \\
BN & 2,379 & 3,877 & 9,195 \\
JP & 442,937 & 479,276 & 769,839 \\
MY & 73,778 & 98,230 & 198,791 \\
SG & 118,263 & 137,806 & 351,867 \\
VN & 5,449 & 14,483 & 71,658 \\
Total & $1,584,516$ & $2,059,555$ & $3,706,635$ \\
\hline
\end{tabular}

means that both parties will have equal negotiation capability when engaging in talks for the formation of the FTAAP.

\section{Current Account Balance}

As an index, the current account balance demonstrates the biggest differences between the EAFTA and the TPP. Figure $2 \mathrm{a}$ and $\mathrm{b}$ shows this point clearly. Although the current balances of most EAFTA countries are in the black, if we observe the current balances of TPP countries, we can see that the US deficit is wiping out the black figures of all TPP countries. Therefore, after the TPP unites 

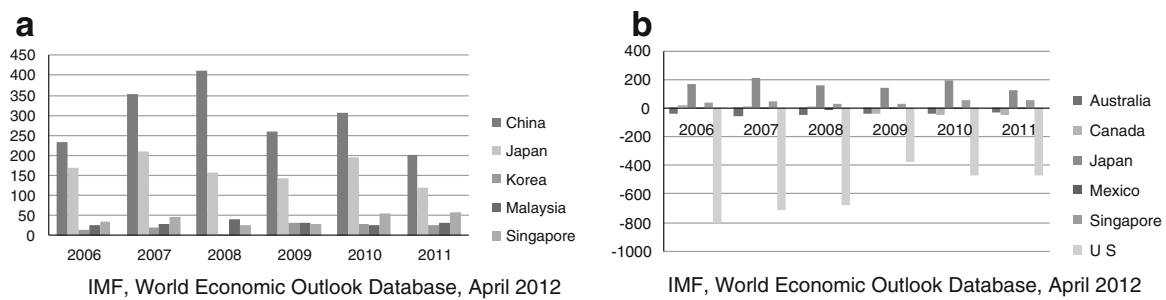

Fig. 2 a C/A: ASEAN + 3, 5 Countries. b C/A: TPP, 6 Countries

with EAFTA, the resultant FTAAP will wipe out the black figures and deficit. Of course, the current balance of a community unit is not the same as the current balance of a country unit. The United States may still be in the red, and China may still be in black figures.

Will these deficit countries and surplus countries disappear after the FTAAP is formed? (Incidentally a policy objective of both EAFTA and the TPP). This is the real intention of "Win-Win".

\section{Trade Matrix: EAFTA}

Table 4 shows the Trade Matrix of the CJKFTA. As is demonstrated, the trade structure of the three countries reaches a huge economic strength within EAFTA. A trade specialization coefficient is adopted in this analysis, which translates to the following: in the China-Japan context, Japan is winning; in the China-Korea context, Korea is constantly winning; in the Japan-Korea context, Japan is winning; in the China-ASEAN context, ASEAN is winning; in the Japan-ASEAN context, Japan is winning; and finally, in the Korea-ASEAN context, Korea is winning.

This table demonstrates that the most competitive trading power within EAFTA is that of Japan. This not only demonstrates the strength of Japan's industrial technology, but is also indicative of Japan's consecutive protection of sensitive industry (=agriculture) and its insistency to keep it away from trade. In order to develop a win-win relationship between EAFTA member countries, it is essential that Japan puts an end to its excessive protection of agriculture. This will also prove to be very important for the fusion of EAFTA and the TPP, too.

\section{Trade Structure by Trade Code}

Figure 3 (split into 6 graphs) shows the export of several commodities from China, Japan and Korea in 2000, 2005 and 2010 respectively. The commodities listed here are selected from single figure SITC codes. The commodities are "total all products", "manufactures with low skill and technology intensity", "manufactures with high skill and technology intensity", "food and live animals", "textile yarn and related products", "miscellaneous manufactured articles, etc.".

The 6 graphs which make up Fig. 3 demonstrate that between the CJK countries, horizontal trade is built mostly with a focus on high-end commodities. 
Table 4 EAFTA trade matrix

\begin{tabular}{lllll}
\hline & Partner & 2000 & 2005 & 2010 \\
\hline $\mathrm{CN}$ & $\mathrm{JP}$ & 1.37 & 1.05 & 0.81 \\
$\mathrm{CN}$ & KR & 0.61 & 0.57 & 0.58 \\
$\mathrm{CN}$ & ASEAN & 0.80 & 0.80 & 0.97 \\
$\mathrm{JP}$ & KR & 1.66 & 1.94 & 2.20 \\
$\mathrm{JP}$ & ASEAN & 1.41 & 1.04 & 1.12 \\
KR & ASEAN & 1.29 & 1.05 & 1.23 \\
\hline
\end{tabular}

\section{Source UNCTADSTAT}

1+, Ex country's Black; 1-, Ex country's Red
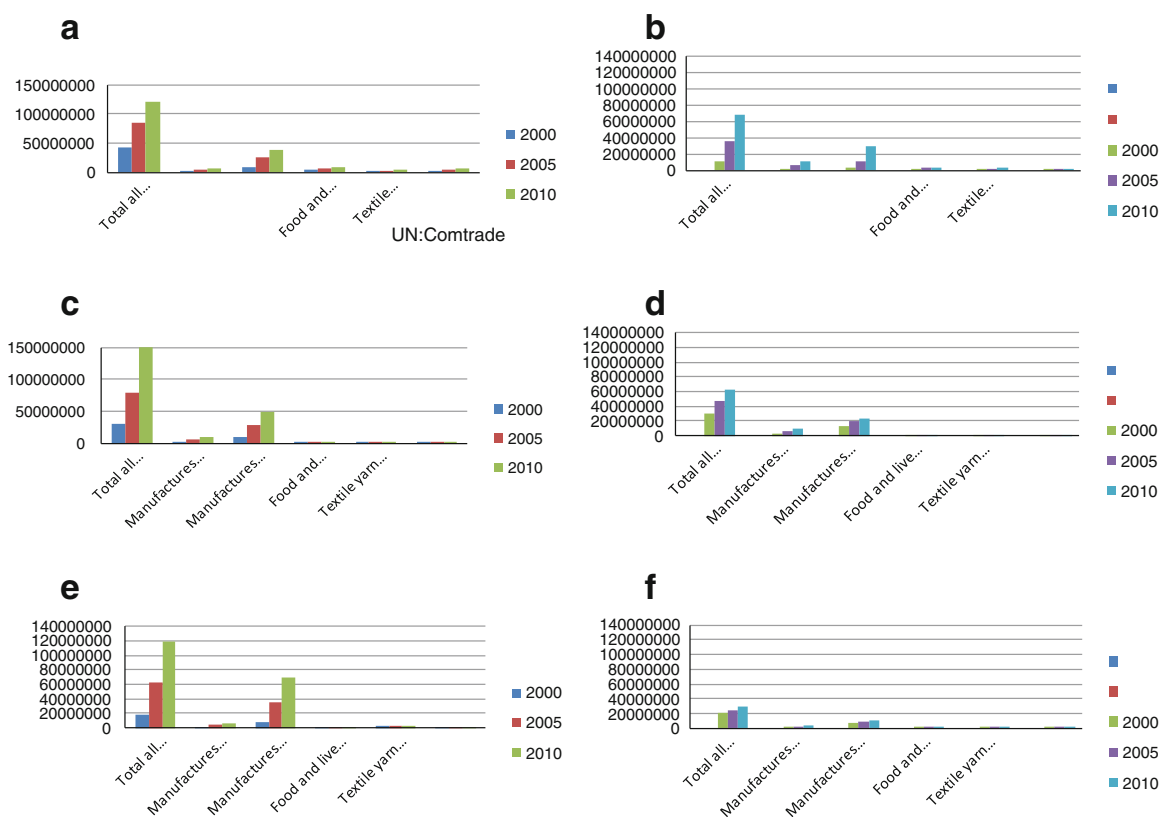

Fig. 3 a Export: China $\rightarrow$ Japan. b Ex: China $\rightarrow$ Korea. c Ex: Japan $\rightarrow$ China. d Ex: Japan $\rightarrow$ Korea. e Ex: Korea $\rightarrow$ China. f Ex: Korea $\rightarrow$ Japan. Source UNCTAD 1000US\$

- Food occupies the largest quantity of exports from China to Japan.

- China is a trade nexus of high-end, low-end and food exports to ASEAN countries.

- China occupies the leading role in ASEAN trade.

In the trade for ASEAN, China has already played a major role. This role will undoubtedly continue to expand. One can easily imagine that China will accrue big black figures in the process.

This point becomes a barrier for community construction of EAFTA. What is a required measure in order to remove these barriers or to make it reduce? The answer is transferring the Chinese manufacturing industry to various parts of ASEAN. That is, China should increase direct investments in ASEAN. 
Trade Specialization Index in EAFTA

My analysis (no data is shown here) shows the competitive power in 2010 of CJK and EAFTA. According to this, China is ahead of five countries: Cambodia, Myanmar, Vietnam, and Singapore. Japan is ahead of seven: Singapore, South Korea, Laos, Thailand, the Philippines and China. South Korea is ahead of eight, except Malaysia, Indonesia, Japan and Brunei. I have already described the reason for this. Although competitive powers such as Japan excel in industrial knowhow, it is in trade protection policy of industry in which it is inferior Table 5.

\section{Tariffs of the Two Blocs}

\section{EAFTA's Tariffs}

There are various barriers to economic integration, including customs duty, nontariff barriers, rules of origin, investment rules and so on. Among these the most serious barrier is that of customs duty. I will now compare the respective tariff levels of EAFTA and TPP. Table 6 shows the customs duty $(2009,2010)$ of CJK which averaged the entire commodity. According to this table, the country where customs duty is the highest is Korea, followed by China. The country with the lowest one is Japan.

This means that agricultural products are the most sensitive products for Korea and Japan. On the other hand, Chinese non-agricultural products tariffs are the highest. And for China, high level industrial products are sensitive goods. Tariff levels differ also in having considered the three countries of CJK. It is forecast that it is difficult to carry out adjustments.

\section{TPP Tariffs}

Figure 4 shows the tariff levels of TPP countries. According to this, the customs duty of developing countries, such as Vietnam, Malaysia, Chile and Peru is high,

Table 5 Trade Specialization Index: 2010

\begin{tabular}{lclllr}
\hline $\mathrm{CN} \rightarrow \mathrm{KH}$ & 0.870 & $\mathrm{JP} \rightarrow \mathrm{KH}$ & -0.132 & $\mathrm{KR} \rightarrow \mathrm{KH}$ & 0.774 \\
$\mathrm{CN} \rightarrow \mathrm{MY}$ & 0.565 & $\mathrm{JP} \rightarrow \mathrm{MY}$ & -0.191 & $\mathrm{KR} \rightarrow \mathrm{MY}$ & 0.508 \\
$\mathrm{CN} \rightarrow \mathrm{VN}$ & 0.536 & $\mathrm{JP} \rightarrow \mathrm{VN}$ & 0.0004 & $\mathrm{KR} \rightarrow \mathrm{VN}$ & 0.496 \\
$\mathrm{CN} \rightarrow \mathrm{SG}$ & 0.133 & $\mathrm{JP} \rightarrow \mathrm{SG}$ & 0.511 & $\mathrm{KR} \rightarrow \mathrm{SG}$ & 0.330 \\
$\mathrm{CN} \rightarrow \mathrm{ID}$ & 0.027 & $\mathrm{JP} \rightarrow \mathrm{ID}$ & -0.277 & $\mathrm{KR} \rightarrow \mathrm{ID}$ & -0.212 \\
$\mathrm{CN} \rightarrow \mathrm{JP}$ & -0.105 & $\mathrm{JP} \rightarrow \mathrm{CN}$ & 0.105 & $\mathrm{KR} \rightarrow \mathrm{CN}$ & 0.270 \\
$\mathrm{CN} \rightarrow \mathrm{LA}$ & -0.109 & $\mathrm{JP} \rightarrow \mathrm{LA}$ & 0.246 & $\mathrm{KR} \rightarrow \mathrm{LA}$ & 0.703 \\
$\mathrm{CN} \rightarrow \mathrm{PH}$ & -0.169 & $\mathrm{JP} \rightarrow \mathrm{PH}$ & 0.167 & $\mathrm{KR} \rightarrow \mathrm{PH}$ & 0.263 \\
$\mathrm{CN} \rightarrow \mathrm{TH}$ & -0.254 & $\mathrm{JP} \rightarrow \mathrm{TH}$ & 0.239 & $\mathrm{KR} \rightarrow \mathrm{TH}$ & 0.226 \\
$\mathrm{CN} \rightarrow \mathrm{KR}$ & -0.270 & $\mathrm{JP} \rightarrow \mathrm{KR}$ & 0.367 & $\mathrm{KR} \rightarrow \mathrm{JP}$ & -0.367 \\
$\mathrm{CN} \rightarrow \mathrm{BN}$ & -0.288 & $\mathrm{JP} \rightarrow \mathrm{BN}$ & -0.927 & $\mathrm{KR} \rightarrow \mathrm{BN}$ & -0.916 \\
$\mathrm{CN} \rightarrow \mathrm{MY}$ & -0.359 & $\mathrm{JP} \rightarrow \mathrm{MY}$ & -0.191 & $\mathrm{KR} \rightarrow \mathrm{MY}$ & 0.508 \\
\hline
\end{tabular}

Source UNCTADSTAT 
Table 6 Agri, Non-Agri Tariff of CJK (\%)

\begin{tabular}{|c|c|c|c|c|c|c|}
\hline & \multicolumn{3}{|c|}{ Simple (2010) } & \multicolumn{3}{|c|}{ Weighted (2009) } \\
\hline & Total & Agriculture & Non-Agriculture & Total & Agriculture & Non-Agriculture \\
\hline China & 9.6 & 15.6 & 8.7 & 4.1 & 8.0 & 3.8 \\
\hline Japan & 4.4 & 17.3 & 2.5 & 2.7 & 15.8 & 1.4 \\
\hline Korea & 12.1 & 48.5 & 6.6 & 7.9 & 99.8 & 3.5 \\
\hline
\end{tabular}

Source Joint Study Report for an FTA among China, Japan and Korea, 2011

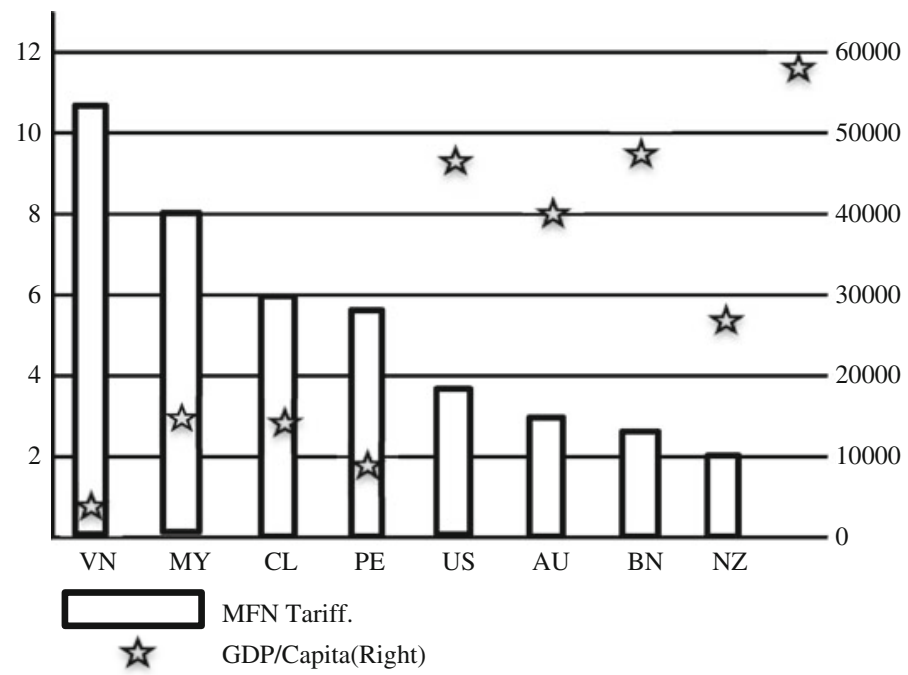

Fig. 4 Average applied tariffs and GDP/capita

while on the other hand, customs duty in the US, Australia, Brunei and New Zealand is low. The customs duty of Singapore is zero. Although the customs duty of TPP countries is divided into two completely different groups, the standard is an economic development grade too. How should this confrontation in tariff levels be adjusted?

\section{Solutions}

It became clear that the gap in customs duty between EAFTA and TPP is so large that it cannot be ignored. The tariff level reflects productivity and resources and cannot be done away with easily. Therefore, I propose the following. It is good to form the international division of labor in the area which unified EAFTA and TPP for this problem as a solution. It is as an economic principle showing that the international division of labor is the fairest method.

An international specialization abolishes the weak industry of the competitive strength of each country, and means strengthening stronger industry further. As a 
result, the pursuer of weak industry loses his place of work. It is a predictable outcome. However, there are many things which are as a matter of fact, impossible. For example, farmers will surely hang on to their profession of farming right through until the bitter end. However, the vast majority of farmers in such cases are people of an age which is approaching 'elderly' or is simply an elderly person. The younger generation does not have a reason for sticking with a weaker industry. They will move to industries with the highest productivity. Therefore, for the elderly farmers, even if income compensation becomes a requirement, those countries that are weaker in agriculture should yield to those foreign countries that are stronger. In a modern society where globalization is accompanied by the breaking down of borders, an international specialization is closer to that of a "local or area specialization".

\section{Cognizance of Sensitive Areas in the Two Blocs}

\section{EAFTA}

EAFTA is one of the symbols of the economic integration of East Asia, and it has become a key agent for realizing further development of this area. About 2 billion people live here. It is also a huge market which occupies $30 \%$ of the world's population. There are high-level industrialized countries such as Japan, China and Korea which have huge financial resources. Furthermore, the economic growth of the ten ASEAN countries has only just begun. ASEAN has the possibility of a high growth rate of the economy. It has a population of 600 million, a GDP of 2 trillion dollars, and a foreign trade of 2 trillion dollars, and further development is also promised. If China, Japan and Korea join ASEAN, an economic integration of the world's largest class will be born.

EAFTA will be satisfactorily completed if the economic integration of CJK can be performed. The CJKFTA demonstrates a cooperative posture over sensitive areas. Joint research on the CJK is reported as follows: "To conduct negotiations in constructive and positive manner, with due consideration to the sensitive sectors in each country." 2

They say that to enhance the competitiveness of the industries of China, Japan and Korea and to elevate their consumers' welfare. To conduct negotiations in a constructive and positive manner, with due consideration paid to the sensitive sectors of each country. Consideration should be given to sensitive products of each country. If issues relating to sensitive products are solved, the three countries will enjoy improved welfare generated by a CJKFTA.

However, they must not forget the following point, either: "A CJKFTA would reveal sensitive sectors in all three countries. In general, the current tariff rates of each country reflect the degree of its sensitivity in terms of trade liberalization. In particular, with regard to a CJKFTA, all three countries will be particularly sensitive to eliminating/reducing tariff rates in the industries where their import dependency

\footnotetext{
2 Governments of CJK (2011).
} 
vis-à-vis the two Northeast Asian trading partners are relatively high." Their mild posture vis-à-vis sensitive problems in the economic-integration plan of EAFTA are down to the following reasons:

(1) When carrying out economic integration, it is certain that asking for economic merits is the first reason.

(2) However, on the other hand, it is indispensable to this area to consider a political situation with friction.

(3) Moreover, there are countries of large economic scale such as Japan and China, and countries whose developmental stage differs from the group which is planning participation to the economic integration.

The actual condition of the economic integration of EAFTA is in a target completing integration first and pursuit of the concrete economic merit is secondary.

As far as integration of EAFTA is concerned, one idea is to focus on agriculture. In this area, agriculture is the most sensitive field. I have studied this integration as "East Asian Agricultural Community". ${ }^{3}$ At the core of this study is the notion that before studying FTA communities in this area, we should think about agricultural communities first. Only then is it acceptable to consider a general agreement for an FTA community is better. That is one of the first stages when considering the EAFTA plan.

\section{TPP}

The original TPP agreement was signed by P4 (Brunei, Chile, New Zealand and Singapore) on June 3, 2005, and entered into force on May 28, 2006. It is a comprehensive free trade agreement, affecting trade in goods, rules of origin, trade remedies, sanitary and phytosanitary measures, technical barriers to trade, trade in services, intellectual property, government procurement and competition policy. Among other things, it called for reduction by $90 \%$ of all tariffs between member countries by January 1, 2006, and reduction of all trade tariffs to zero by the year 2015 . $^{4}$ This is an agreement that is not primarily driven by economic considerations. It is a political statement about binding together different regions of the world. Member countries want to use TPP participation as a means to cement their relationship with Asia. ${ }^{5}$

The economic-integration target of TPP tends to prioritize the advancement of economic unification without considering important terms and conditions such as the economic gaps between each country. Import tariffs are lowered without exception, trade barriers in the service field are abolished, and promotion is aimed at investment. TPP is very severe. It seems that this severity has continued from the TPP's nascent stage as the P4, and its severity has continued to swell following US participation as a negotiator country in 2009. This is what

\footnotetext{
${ }^{3}$ Takahashi (2010).

${ }^{4}$ Government of New Zealand (2005). http://www.mfat.govt.nz/downloads/trade-agreement/transpacific/ main-agreement.pdf.

5 Elms (2009).
} 
distinguishes the TPP from EAFTA. This tendency became even more noticeable after US began participating as a negotiator in 2009. It's clear that one of the objectives of the US is the reinforcement of their competitiveness in the AsiaPacific region. The huge and burgeoning markets of the Asia-Pacific region are already key destinations for US manufactured goods, agricultural products and services. The export of US goods to the broader Asia-Pacific region totaled $\$ 895$ billion in 2011, making up $60 \%$ of total US goods exports. US exports of agricultural products to the region totaled \$98 billion in 2011, making up $72 \%$ of total US agricultural exports. ${ }^{6}$ Major trade and investment negotiations address a broad range of often complex and commercially sensitive sectors and issues, often taking many months or even years to conclude. In order to reach agreements that each participating government can fully embrace, negotiators need to communicate with each other with a high degree of candor, creativity, and mutual trust. ${ }^{7}$

The TPP is the most credible pathway to broader Asia-Pacific regional economic integration. The nine like-minded countries share a commitment to concluding a high-standard agreement and the objective of expanding the initial group to include additional countries from the Asia-Pacific region. The TPP is a key element of the Obama Administration's efforts to support the creation and retention of high-quality jobs for Americans by increasing exports to the vibrant economies of the AsiaPacific region. The US and its TPP partners are determined to swiftly complete a comprehensive, next-generation agreement. ${ }^{8}$

In the case of the $\mathrm{P} 4$ agreement, tariff reductions were also very strict. For example, Chile's tariff reductions were decided as follows: $89.3 \%$ of the imports from New Zealand and Singapore will receive duty-free treatment when the Agreement comes into force on November 8th 2006. The rest of the tariffs will be eliminated as follows: for imports from Singapore, duties on $9.57 \%$ of the imports within the next 3 years, and the remaining imports within the following 6 years; for imports from New Zealand, most of the tariffs will be eliminated by January 1st 2015, with tariffs on Chile's most sensitive dairy products-butter, milk powders and whey-which accounts for $9.26 \%$ of the imports from New Zealand, to be eliminated on January 1, 2017. ${ }^{9}$

Since the US joined the TPP negotiations, it has required high level agreements of tariff reductions and access to the service markets of TPP members." In all likelihood, for the TPP to succeed, this will require more openness to compromise than the US has been required to show in its recent bilateral negotiations." 10 Particularly striking is the almost zero tolerance in the P4 for the exclusion of

\footnotetext{
${ }^{6}$ Office of USTR (2012) http://www.ustr.gov/about-us/press-office/fact-sheets/2012/june/us-tppincreasing-american-exports-supporting-american-jobs.

${ }^{7}$ Office of USTR (2012) http://www.ustr.gov/about-us/press-office/fact-sheets/2012/june/transparencyand-the-tpp.

${ }^{8}$ Office of USTR (2012) http://www.ustr.gov/about-us/press-office/press-releases/2012/june/ustrmexico-new-tpp-partner.

${ }^{9}$ Gao (2009).

${ }^{10}$ Levy (2012).
} 
sensitive sectors. Singapore, New Zealand and Chile agreed to scrap all tariffs and Brunei agreed to $99 \%$ tariff elimination. For American policymakers, building up from a compatible P4 agreement towards a larger TPP presents the advantage of gathering like-minded countries willing to undertake major liberalization commitments. ${ }^{11}$ Because existing FTAs of US have several carve-outs to protect sensitive sectors, the US move creates uncertainty regarding its willingness to negotiate without exclusions. Australia for instance had hoped to use the TPP to secure market access concessions in sugar, but so far these hopes have been dashed. The American Manufacturing Trade Action Coalition has come out strongly against any exclusions for reduction of tariffs.

\section{Conclusions; Load to FTAAP, AP Community}

Observing EAFTA and TPP, (1) the difference in posture to sensitive problems, and (2) barriers and solutions in case the two economic-integration plans are unified as one were discussed. The FTAAP is the form by which economic integration would take place, and it is possible at this point to aim at forming an Asia-Pacific community which transcends economic integration. The two economic-integration plans have differences in posture as far as sensitive problem are concerned, and there are barriers in the achievement of unification. An integrated plan would only be attained after the barriers are removed. Integration of EAFTA and TPP is waiting, and there are barriers in this integration also. Such barriers include differences in various fields, such as economic conditions, political conditions, cultural conditions, historical conditions and international relations.

Cancelling such differences would be difficult. However, these differences will also serve as the terms of promotion and conditions to integration. Just as there are differences, we can also recognize the necessity for mutual complements. The case of the EU can be applied to this. The unification of 27 states to form the EU was not achieved because of the comparability argument; it was achieved thanks to the differences which exist between member states. Although the EU is in a state of historical crisis, the cause of this lies in the failure of the public-finance policy of certain member states. While learning from the EU experience, EAFTA and the TPP should merge to form the FTAAP, with the ultimate goal of APC establishment in the future.

In order to perform economic integration and serve as a mutual complement, it is necessary to respect the differences in the terms and conditions of affiliation between each country. In integration, the parties interested should mutually avoid sensitive problems and should agree on what they can agree.

It is not necessary to adjust differences in the terms and conditions of each country when beginning integration. Rather, utilizing the differences should be an important part of policy. However, if the sensitive problems of each country are perpetually neglected, the meaning of economic integration fades. In order to

11 Solis (2011). 
achieve the desired effect of economic integration, it is necessary to realize steps such as reduction in import tariffs, and the abolishment of nontariff walls, after progress for a fixed period has been achieved.

\section{References}

Elms D (2009) From the P4 to TPP: explaining expansion interests in the Asia-Pacific. ARTNeT, UNESCAP and UNDP

Gao H (2009) The Trans-Pacific Strategic Economic Partnership Agreement: high standard or missed opportunity? Asia-Pacific trade economists' conference on trade-led growth in times of crisis held in Bangkok

Government of New Zealand (2005, Retrieved 2012) Trans-Pacific Strategic Economic Partnership Agreement. http://www.mfat.govt.nz/downloads/trade-agreement/transpacific/main-agreement.pdf

Governments of CJK (2011) Joint Study Report for an FTA among China, Japan and Korea http://www.ustr.gov/about-us/press-office/fact-sheets/2012/june/us-tpp-increasing-american-exportssupporting-american-jobs

http://www.ustr.gov/about-us/press-office/fact-sheets/2012/june/transparency-and-the-tpp

http://www.ustr.gov/about-us/press-office/press-releases/2012/june/ustr-mexico-new-tpp-partner

Levy PI (2012) The potential of the Trans-Pacific Partnership Trade Agreement. House Committee on Foreign Affairs Subcommittee on Terrorism, Nonproliferation, and Trade Subcommittee on Asia and the Pacific

Ministry of Foreign Affairs of Japan (2012) Japanese activities on EPA, aspects of other main countries and regions

Solis M (2011) Last train for Asia-Pacific Integration? US Objectives in the TPP Negotiations. Waseda University Organization for Japan-US Studies Working Paper No. 201102

Takahashi G (2010) The need of East Asian Agricultural Community and the Framework. Procedia Agriculture 